\title{
MATHEMATIC EDUCATION'S DIDACTIC TESTS IN THE PROGRAM HOT POTATOES OF THE THEME SOLVING LINEAR EQUATIONS
}

\section{Tatiana PREXTOVÁ}

\begin{abstract}
In the article we present a variant of the mathematic education's didactic test created in the program Hot Potatoes, which deal with the theme solving linear equations. The role of the didactic test is not only the investigating of the knowledge and the understanding of students of the topic, but also the verification their thought processes and mathematic reasoning for the solving of the word tasks of the move, the working together and the blends; for the tasks focusing on the search of the unknown numbers and on the calculation of people's age.
\end{abstract}

Key words: mathematics, didactic test, the program Hot Potatoes, linear equations.

\section{DIDAKTICKÉ TESTY Z MATEMATIKY V PROGRAME HOT POTATOES V RÁMCI TEMATICKÉHO CELKU RIEŠENIE LINEÁRNYCH ROVNÍC}

Resumé: V príspevku uvádzame jeden variant didaktického testu z matematiky vytvorený v programe Hot Potatoes, ktorý sa obsahovo týka tematického celku Riešenie lineárnych rovníc. Úlohou didaktického testu je nielen zistenie vedomosti a poznatkov žiakov z danej témy, ale aj overenie ich myšlienkových pochodov a matematického uvažovania pri riešeni slovných úloh o pohybe, spoločnej práci a zmesiach; pri úlohách zameraných na hl’adanie neznámeho č́sla a zistovanie veku osôb.

Kl'účové slová: matematika, didaktický test, program Hot Potatoes, lineárne rovnice.

\section{1 Úvod}

Didaktický test je užitočným nástrojom, ktorý informuje učitel'a o vedomostiach, poznatkoch a zručnostiach jednotlivých žiakov. Jedna z primeraných a výstižných definícií chápe pod pojmom didaktický test „nástroj na systematické zistovanie (meranie) výsledkov vyučovania“ [2]. Didaktický test má hned' niekol'ko základných predností: testovanie širokého spektra učiva, hodnotenie vel'kého množstva žiakov, umožňuje objektívne porovnávanie úrovne vedomostí, jeho používanie je jednoduché, efektívnost' hodnotenia (realizácia v krátkom čase), vyššia reliabilita [1].

Ked’že sa v súčasnej dobe čoraz viac dostávajú do popredia informačnokomunikačné technológie (IKT), ponúka sa nám možnost' využitia IKT pri riešení didaktického testu. Žiak pri práci s počítačom sa spolieha sám na seba, pracuje vlastným tempom a neviaže sa na ostatných spolužiakov. Počítač dokáže kontrolovat' dosiahnuté výsledky jednotlivých žiakov a poskytuje im spätnú väzbu často ovel'a rýchlejšie ako samotný učitel'. Už len samotná prítomnost' počítačov vo vyučovaní vzbudzuje u žiakov záujem, motivuje ich $\mathrm{k}$ dosiahnutou lepších výsledkov, spestruje samotný priebeh vyučovacieho procesu.

Našim zámerom bolo vytvorenie testu overujúceho vedomosti $\mathrm{z}$ tematického celku Riešenie lineárnych rovníc. Sú to úlohy určené žiakom 8. ročníkov základných škôl. Vytvorili sme dokopy 10 variant testu, z ktorých každý obsahuje 10 úloh. Obt'ažnost' jednotlivých testov postupne narastá od prvého testu, až po test posledný. Ďalej sme vytvorili aj tzv. doplňovacie cvičenia. Ciel'om jednotlivých úloh je vediet' riešit' lineárnu rovnicu s jednou neznámou; rôzne typy slovných úloh, ktoré vedú $\mathrm{k}$ lineárnym rovniciam $\mathrm{s}$ jednou neznámou a viest' žiakov k racionálnemu spôsobu riešenia slovných úloh [7]. Tvorbu testov sme realizovali v programe Hot Potatoes, ktorého užívatel'ské prostredie je na ovládanie a tvorbu testov vel'mi jednoduché. Testy sú vol'ne prístupné na e-learningovom portáli s názvom „Vieš, čo vieš“ (http://vcv.truni.sk), v sekcii Testy (výber podl'a ročníka alebo podl'a predmetu).

\section{Tvorba didaktického testu}

Dôležitým krokom pri konštrukcii didaktického testu je počet testových úloh. $\mathrm{Na}$ počet vplýva viacero faktorom, medzi najdôležitejší zarad'ujeme reliabilitu. Čím väčší 
počet úloh obsahuje test, tým jeho reliabilita vzrastá. Preto by malo byt' súčast'ou didaktického testu čo najväčší počet úloh. Za dolnú hranicu považujeme asi 10 testových položiek [4].

Pri návrhu testových úloh vychádzame $\mathrm{z}$ viacero možností. $\mathrm{V}$ prvom rade sa rozhodujeme medzi úlohami otvorenými a uzavretými. Pri otvorených úlohách vychádzame z jednotlivých odpovedí žiakov. Ak sa od žiaka vyžaduje rozsiahlejšia odpoved' - niekol'ko viet - jedná sa o otvorené úlohy so širokou odpoved'ou. Ak však žiak odpovedá stručne - jeho odpoved'ou je symbol, značka, jedna veta, číslo, vzorec - máme na mysli otvorenú úlohu so stručnou odpoved'ou [1].

Pri uzavretých úlohách sa nám ponúka hned' niekol'ko možností:

a. Dichotomické úlohy - ako odpoved' sú ponúkané vždy dve alternatívy, z ktorých je jedna správna. Ich výhodou je, že sa vel'mi jednoducho navrhujú.

b. Prirad'ovacie úlohy - jedná sa o dve skupiny pojmov a žiakovou úlohou je správne priradit' pojmy jednej skupiny k pojmom druhej skupiny. Výhoda tejto úlohy spočíva v obmedzení možnosti uhádnutia správnej odpovede na minimum.

c. Usporiadacie úlohy - tento typ úlohy spočíva v usporiadaní jednotlivých prvkov určitej množiny do radu (podl'a vel'kosti, tvaru, farby...).

d. Úlohy s výberom odpovede takáto úloha pozostáva $\mathrm{z}$ dvoch častí: problém a k nemu je daná množina ponúkaných odpovedí [4].

Úlohy s výberom odpovede sa spájajú aj s tvorbou vhodných distraktorov (nesprávne odpovede). Optimálny počet ponúkaných možností na danú položku je 4 až 5 odpovedí, medzi ktorými je správna odpoved' a odpovede nesprávne. Distraktory však nevyberáme náhodným spôsobom. Bud' predstavujú logicky možné odpovede, alebo typicky chybné odpovede (ktoré sú výsledkom nedostatočného zvládnutia testovaného učiva) [1]. Samotné distraktory by nemali inou formou vyjadrovat' to isté, nemali by sa prekrývat'. Navrhujeme ich tak, že predpokladáme ich využitie pri výbere správnej odpovede. Správnu odpoved' včleňujeme medzi distraktory náhodne, bez nejakého konkrétneho poradia.

Zaujímavý spôsob nájdenia vhodných distraktorov je zadat' konkrétnu úlohu ako otvorenú položku a najčastejšie sa vyskytujúce chyby využijeme ako distraktory [4].

\section{Charakteristika didaktického testu}

Jednotlivé didaktické testy boli zostavené podl'a obt'ažnosti testových položiek. Test s názvom Lineárne rovnice 1 obsahuje položky najmenej obt'ažné a test s názvom Lineárne rovnice 10 ponúka úlohy $\mathrm{s}$ najväčšou obt'ažnost'ou. Ked’že v rámci každého toho testu sú úlohy obsahovo si podobné, ale samotné testy sa medzi sebou líšia svojou obt'ažnost'ou, charakterizujeme z každého testu po jednej úlohe. Čo sa týka spomínaných doplňovacích cvičení, každé z nich obsahuje 10 jednoduchých obsahovo si podobných zadaní, takže opät' charakterizujeme iba jedno z nich. Z hl'adiska rôznych kritérií môžeme zaradit' test medzi testy vedomostí (z hl'adiska diagnostiky), testy overovacie ( $\mathrm{z}$ hladiska spôsobu interpretácie), testy výstupné ( $\mathrm{z}$ hl'adiska účelu) a testy objektívne skórovatel'né ( $\mathrm{z}$ hl'adiska vyhodnocovania testu) [6]. Každý test je vytvorený vo forme kvízu - 10 zadaní. Doplňovacie cvičenia ponúkajú žiakovi možnost' doplnit' správnu odpoved'.

\section{Doplňovacie cvičenie}

Doplň prázdne miesta, potom stlač "Over" a uvidíš, či si doplnil správny výraz. Ak nevieš ako d'alej, použi tlačidlo "Rada" a dostaneš d'alšie správne písmeno odpovede, ale stratîs body zo skóre!

a) $2 x+1=3$

$2 x=\cdots$

$x=\cdots$

b) $9 x+3=-15$

$9 x=\ldots$

$x=\cdots$

V tomto prípade sa jedná o otvorenú položku s krátkou odpoved'ou; doplňovaciu. Úlohou žiaka je doplnit' na chýbajúce miesta správne číslice, prípadne aj vhodné znamienko operácie. Ak má problém s doplnením správnej odpovede, kliknutím na tlačidlo Rada sa mu zobrazí pomôcka (prvé písmeno, číslo alebo 
znak zo správnej odpovede). S využitím tohto tlačidla však žiak stráca možnost' získat' 100\% za správne zodpovedané cvičenie. Ked’že ide o samostatnú úlohu, vyhodnocuje sa ihned'.

\section{Lineárne rovnice 1}

Majú rovnice
a) $8 x=16$
b) $-x=-2$

rovnaké riešenie?
A. áno
B. nie

V úlohe ide o riešenie sústavy dvoch lineárnych rovníc s jednou neznámou, položka je uzavretá a dichotomická. Žiak má posúdit', či je otázka pravdivá alebo nepravdivá.

\section{Lineárne rovnice 2}

Majú rovnice
a) $5 x-2=2 x+3$
b) $(5 x / 2)-1=x-(3 / 2)$

rovnaké riešenie?
A. áno
B. nie

V tomto zadaní, podobne ako v predchádzajúcej úlohe, riešia žiaci sústavu dvoch lineárnych rovníc s jednou neznámou, pričom položka je uzavretá a dichotomická. Žiak má rozhodnút', či je otázka pravdivá alebo nepravdivá.

\section{Lineárne rovnice 3}

Aký dvojčlen musíme pripočítat' $\mathrm{k}$ obom stranám rovnice $x-2=-6 x-4$ aby l'avá strana upravenej rovnice obsahovala len jeden člen $\mathrm{s}$ neznámou $\mathrm{x}$ a pravá strana obsahovala iba jedno číslo?
A. $-6 x+2$
B. $-x+2$
C. $2+6 x$
D. $6 x+4$

Pri tejto úlohe žiak využíva postupy patriace do ekvivalentných úprav $\mathrm{v}$ rámci riešenia lineárnych rovníc. Položka je uzavretá s výberom jednej odpovede.

\section{Lineárne rovnice 4}

Aký dvojčlen musíme pripočítat' $\mathrm{k}$ obom stranám rovnice $-1,3 x+1,8=0,4 x-2$ aby l'avá strana upravenej rovnice obsahovala len jeden člen $\mathrm{s}$ neznámou $\mathrm{x}$ a pravá strana obsahovala iba jedno číslo?
A. $-0,4 x+1,8$
B. $-0,4 x-1,8$
C. $0,4 x+1,8$
D. $0,4 x-1,8$

Úloha sa zameriava na využitie ekvivalentných úprav pri riešení lineárnych rovníc. Položka je opät' uzavretá s výberom jednej odpovede.

\section{Lineárne rovnice 5}

Jeden pracovník vykoná určitú prácu za 10 hodín, druhý za 15 hodín. Za kol'ko hodín vykonajú túto prácu, ak budú pracovat' obaja spoločne?
A. 6
B. 5
C. 3
D. 25

Žiak v tomto zadaní rieši slovnú úlohu zameranú na spoločnú prácu. Cvičenia tohto typu poukazujú na dôležitost' vzájomnej spolupráce a tiež na to, že výkon celého kolektívu je ovel'a vyšší ako len súčet jednotlivých výkonov členov tohto kolektívu. Položka je uzavretá, s výberom jednej správnej odpovede.

\section{Lineárne rovnice 6}

Za chodcom idúcim priemernou rýchlost'ou 5 $\mathrm{km} / \mathrm{h}$ vyrazil $\mathrm{z}$ toho istého miesta o 3 hodiny neskôr cyklista $\mathrm{s}$ priemernou rýchlost'ou 20 $\mathrm{km} / \mathrm{h}$. Za kol'ko hodín doženie cyklista chodca?
A. nedá sa určit'
B. 3
C. 1
D. 2
E. 4

Žiak rieši $\mathrm{v}$ tomto cvičení slovnú úlohu zameranú na rovnomerný pohyb. V týchto úlohách nie je tak dôležité, či je pohyb rovnomerne priamočiari, ale že rýchlost' uvedená $\mathrm{v}$ zadaní zostáva $\mathrm{v}$ priebehu celého pohybu viac menej nemenná. Úloha má podobu uzavretej položky s výberom jednej správnej odpovede. 


\section{Lineárne rovnice 7}

Otec má 42 rokov, syn 12 rokov. O kol'ko rokov bude mat' otec dvakrát tol'ko rokov ako syn?
A. 30
B. 8
C. 18
D. 6

Nasledujúca úloha je zadanie, ktoré spadá do kategórie slovných úloh na zistovanie veku osôb. Opät’ je to položka uzavretá s výberom práve jednej správnej odpovede.

\section{Lineárne rovnice 8}

Za 10 lístkov do kina (po 5 Eur a po 8 Eur) sme zaplatili 62 Eur. Kol'ko lístkov sme kúpili lacnejších a kol'ko drahších?
A. lacnejšie 3 , drahšie 7
B. lacnejšie 5 , drahšie 5
C. lacnejšie 4 , drahšie 6
D. lacnejšie 6 , drahšie 4
E. lacnejšie 8, drahšie 2

V tomto príklade sa jedná o uzavretú položku s výberom jednej odpovede. Úlohu zarad'ujeme medzi slovné úlohy o zmesiach. $\mathrm{S}$ takýmito úlohami sa stretávame nielen vo fyzike či chémii, ale aj v bežnej praxi.

\section{Lineárne rovnice 9}

Súčet troch za sebou idúcich celých čísel je 27. Ktoré sú to čísla?
A. $7,8,9$
B. $9,10,11$
C. $8,9,10$

Jedná sa o nájdenie niekol'kých neznámych čísel. Žiak zodpovedá položku uzavretú, s výberom jednej odpovede.

\section{Lineárne rovnice 10}

Súčet štyroch za sebou idúcich prirodzených čísel je 38. Ktoré sú to čísla?
A. $7,8,9,10$
B. $8,9,10,11$
C. $9,10,11,12$
D. $10,11,12,13$

V úlohe vidíme uzavretú položku s výberom jednej odpovede. Žiak má určit', ktorá odpoved' na danú otázku je správna. Ide o typ slovnej úlohy, pri ktorej sa hl'adajú neznáme čísla.

\section{Vlastnosti didaktického testu}

Medzi dôležité vlastnosti didaktického testu patria: validita a reliabilita. Validný test je taký, ktorý naozaj meria to, čo ním merat' chceme, či skutočne zist'uje vedomosti z oblasti, ktorú preveruje. V takomto prípade máme na mysli obsahovú validitu [4]. Validitu testu môže ovplyvnit' množstvo faktorov, ako sú:

- nejasné alebo nezrozumitel’né pokyny

- jazyk používaný v teste je obt'ažný

- úlohy príliš l'ahké alebo príliš t'ažké

- nejednoznačné úlohy

- zlá administrácia testu

- testy sú vyhodnotené nesprávne a podobne [6].

Pod pojmom reliabilita rozumieme presnost', s akou sa didaktickým testom merajú vedomosti žiakov [5]. Na reliabilitu, podobne ako aj na validitu, môže pôsobit' viacero faktorov:

- čím má test väčší počet úloh, tým má vyššiu reliabilitu

- málo obt’ažné alebo príliš obt’ažné úlohy znižujú reliabilitu

- čím je počet testovaných žiakov väčší, tým je reliabilita vyššia [1].

Reliabilitu môžeme vel'mi jednoducho vypočítat' podl'a Kuderovho-Richardsonovho vzorca:

$$
r=\frac{k}{k-1}\left(1-\frac{\sum p q}{s^{2}}\right)
$$

kde $k$ je počet úloh $\mathrm{v}$ teste, $p$ je podiel žiakov, ktorý vyriešili určitú úlohu v teste správne, $q=1-p$ a $s$ je smerodajná odchýlka $\mathrm{v}$ rámci celkových výsledkov žiakov v danom teste [4].

Ďalšou nemenej významnou vlastnost'ou didaktického testu je obtažnost' jednotlivých testových úloh. Táto vlastnost' nám vypovedá o tom, ktoré úlohy v teste sú príliš jednoduché, alebo naopak, príliš zložité. Koeficient obt’ažnosti môžeme vypočítat' pomocou nasledujúceho vzorca:

$$
q_{i}=1-N_{i} / N
$$

kde $N_{i}$ je počet žiakov, ktorí na $i$-tú otázku odpovedali správne a $N$ je celkový počet testovaných žiakov [3].

Citlivost' položiek je d'alšia z vlastností didaktického testu. Vyjadruje to, ako daná úloha zvýhodňuje žiakov s lepšími 
vedomost'ami, pred žiakmi s vedomost’ami slabšími. Spol'ahlivou metódou na zistenie citlivosti je použitie tzv. tetrachorického koeficientu citlivosti. Pri tomto výpočte používame štyrpol'nú tabul'ku:

$$
\begin{array}{lll|l|} 
& & \multicolumn{2}{c}{\text { odpoved }} \\
\multicolumn{1}{c}{} & & \multicolumn{1}{c}{-} \\
\cline { 3 - 4 } \text { skupina } & \mathrm{L} & a & b \\
\cline { 3 - 4 } & \mathrm{H} & c & d \\
\cline { 3 - 4 } & & &
\end{array}
$$

kde cos patrí medzi goniometrické funkcie a hodnota čísel $a, b, c, d$ vyplýva $\mathrm{z}$ hore uvedenej tabul'ky [4].

\section{Záver}

Ako sme už spomínali, testy sú sprístupnené na internetovej stránke „Vieš, čo vieš“. Vzhl'adom na to, že doba riešenia ešte stále prebieha (2010 - 2011), samotné výsledky testovania budú $\mathrm{k}$ dispozícii až po ukončení celého projektu.

\section{Literatúra}

[1] BURJAN, V. Tvorba a využívanie školských testov v pedagogickej praxi. Bratislava: Metodicko-pedagogické centrum, 2005. s. 7, 3334. ISBN 80-8052.228-6.

[2] BYČKOVSKÝ, P. Základy měření výsledků výuky. Tvorba didaktického testu. Praha: ČVUT, 1982.

[3] HRABAL, V., LUSTIGOVÁ Z., VALENTOVÁ L. Testy a testování ve škole. pričom L sú žiaci lepší, H žiaci horší, + znamená správnu odpoved', - odpoved' nesprávnu respektíve nezodpovedanú. Citlivost' tak vypočítame na základe vzorca:

$$
r_{\text {tet }}=\cos \left(180 \frac{\sqrt{b c}}{\sqrt{b c}+\sqrt{a d}}\right)
$$

Praha: Pedagogická fakulta UK, 1992. s. 86. ISSN 0862-156x.

[4] CHRÁSKA, M. Didaktické testy. Brno: Paido, 1999. s. 17, 50, 59. ISBN 80-85931-68-0.

[5] LAPITKA, M. Tvorba a použitie didaktických testov. Bratislava: SPN, 1990. s. 31. ISBN 80-08-00782-6.

[6] ROSA, V. Metodika tvorby didaktických testov. Bratislava: Štátny pedagogický ústav, 2007. s. 28-29, 39. ISBN 978-80-89225-32-3.

[7] Učebné osnovy. Matematika pre 5. až 9. ročník základnej školy. [online]. 13.05.2011. Dostupné na internete: http://www2.statpedu.sk/ buxus/generate page.php_page id=331.html.

Mgr. Tatiana Prextová

Katedra informačních a komunikačních

technologií

Pedagogická fakulta OU

Českobratrská 16

7701 03, Ostrava, ČR

Tel: +420 728648563

E-mail: d10577@student.osu.cz

Www pracoviska: http://pdf.osu.cz/kik/ 